Pamiętnik Literacki 2021, 2, s. 7-21

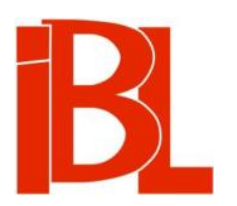

\title{
Oświeceni o śmieszności (komizmie) i śmiechu. W perspektywie retorycznej, moralnej, estetycznej
}

Roman Dąbrowski 


\section{1. $\begin{array}{llllllllllllllllllll} & \mathrm{R} & \mathrm{O} & \mathrm{Z} & \mathrm{P} & \mathrm{R} & \mathrm{A} & \mathrm{W} & \mathrm{Y} & \mathrm{I} & \mathrm{A} & \mathrm{R} & \mathrm{T} & \mathrm{Y} & \mathrm{K} & \mathrm{U} & £ & \mathrm{Y}\end{array}$}

Pamiętnik Literacki CXII, 2021, z. 2, PL ISSN 0031-0514

DOI: $10.18318 / \mathrm{pl} .2021 .2 .1$

ROMAN DĄBROWSKI Uniwersytet Jagielloński, Kraków

\section{OŚWIECENI O ŚMIESZNOŚCI (KOMIZMIE) I ŚMIECHU W PERSPEKTYWIE RETORYCZNEJ, MORALNEJ, ESTETYCZNEJ}

Pojęcia śmieszności, komizmu, śmiechu i inne z nimi mniej czy bardziej związane należą, jak wiadomo, do kluczowych kategorii używanych w charakterystyce i interpretacji piśmiennictwa okresu oświecenia. Stają się one oczywiście także niejednokrotnie tematem formułowanych $\mathrm{w}$ interesujacej nas epoce $-\mathrm{z}$ rozmaitych punktów widzenia, w różnych kontekstach i formach - uwag oraz refleksji, ilustrując w dużej mierze ówczesną świadomość w tym zakresie, jej dominanty i przemiany. Odzwierciedlaja ją i kształtują m.in. istotne wątki w myśli filozoficznej ${ }^{1}$, XVIII-wiecznej i przywołanej z dawniejszych tradycji. Przykładowo można tu wspomnieć: $\mathrm{z}$ jednej strony, poglądy Thomasa Hobbesa, akcentującego poczucie wyższości śmiejącego się nad obiektem jego śmiechu ${ }^{2}, z$ drugiej - proponującego „test śmieszności” dla rozstrzygania o rzeczywistej powadze spraw i podkreślającego pozytywną rolę dobrego humoru Antony'ego Ashley'a Shaftesbury'ego ${ }^{3}$, także Davida Hume'a, który dostrzega znaczenie przyjemności związanej z humorem i dowcipem ${ }^{4}$, czy wreszcie wyjaśniającego swoje rozumienie komizmu w wywodach na temat kwestii estetycznych Immanuela Kanta ${ }^{5}$. Stosunek do śmiechu i jego przyczyn przyjmuje w okresie oświecenia różne oblicza, jakkolwiek na czoło wysuwa się pewna podejrzliwość bądź nawet wyraźna niechęć wobec jego spontanicznej żywiołowości, ale

1 Ogólnie na ten temat zob. M. G e i e r, Z czego śmieja się madrzy ludzie. Mała filozofia humoru. Przeł. J. C z u d e c. Kraków 2007, s. 99-131.

2 Zob. Th. Hobbes, Lewiatan, czyli Materia, forma i władza państwa kościelnego i świeckiego. Przeł. Cz. Zn a mi e r ow s ki. Wstęp, przypisy J. C. A. G a s ki n. Warszawa 2005, s. 136: „przyczyną [śmiechu] jest bądź jakieś nagłe działanie tego samego człowieka, któremu ono się podoba, bądź też powstaje przez spostrzeżenie jakiejś deformacji u innego człowieka, której porównanie z własną osobą daje mu nagle poczucie wyższości”.

3 Zob. A. A. Shafte sbury, List o entuzjazmie do Lorda *****. Przeł. A. Grzelińs ki. „Estetyka i Krytyka” 2001, nr 1, s. 131: „Dobry humor jest nie tylko najlepszym zabezpieczeniem przed entuzjazmem, lecz również najlepszym fundamentem pobożności i prawdziwej religii [...]”.

4 Zob. D. Hu m e, Traktat o naturze ludzkiej. Przeł. Cz. Zn a mi e row s ki. T. 2: O uczuciach. Wyd. 2, przejrz. Warszawa 1963, s. 442: „dobry humor lubimy i uważamy, ponieważ jest bezpośrednio przyjemny dla samej osoby, która go posiada. Jest oczywiste, że rozmowa z człowiekiem pełnym dowcipu jest bardzo przyjemna; podobnie wesoły i w dobrym humorze towarzysz rozsiewa radość na całe towarzystwo [...]".

5 I. Kant, Krytyka władzy sadzenia. Przekł., przedm., przypisy J. Gałecki. Przekł. przejrzał A. Landman. Wyd. 2. Warszawa 1986. 
również dążenie do jego dowartościowania poprzez proces „ucywilizowania”, ${ }^{\text {, pod- }}$ dania mniejszej lub większej kontroli rozumu, dobrych obyczajów, a w sferze twórczości artystycznej także gustu.

Wypowiedzi na temat śmieszności i śmiechu odniesione przede wszystkim do tej ostatniej sfery - choć bez rygorystycznego unikania szerszej perspektywy - stana się zasadniczym przedmiotem zainteresowania w niniejszym artykule. Jego celem zaś będzie syntetyczne, oparte na wielostronnym - jakkolwiek ze względu na skalę i złożoność zjawiska - wybiórczym i dość ogólnym oglądzie zaprezentowanie ich treści, z włączeniem szczególnie eksponowanych aspektów omawianego proble$\mathrm{mu}$, wielorakości opinii, zmiany akcentów w sposobie jego ujmowania. Uwaga skupi się na wypowiedziach autorów polskich, chociaż niekiedy zostaną też przywołane opinie formułowane za granica, przeważnie dobrze u nas wówczas znane czy wprost powtarzane w konkretnych przypadkach.

Należy podkreślić, że jednoznaczne rozdzielenie zakresu pojęć związanych z komentowanym zjawiskiem jest tutaj często trudne, gdyż nieraz - jak komizm i śmieszność - używane były one zamiennie lub ich sensy w dużym stopniu się pokrywały. Pierwsze $\mathrm{z}$ nich odnoszono $\mathrm{z}$ reguły do komedii jako gatunku albo w ogóle do utworów literackich, drugie natomiast miało szerszy zakres znaczeniowy, przy czym - co pozwala rezygnować ze skrupulatnego uwzględniania tych rozgraniczeń w toku niniejszego wywodu - w zasadniczej mierze istota problemu pozostaje podobna lub nawet identyczna. Czasem pojawiają się również inne terminy, jak dowcip, kładący akcent na gest intelektualny, żart czy żartobliwość, które eksponują bardziej aktywność w kreowaniu źródeł śmiechu, wreszcie, wskazująca raczej na poczucie humoru, wesołość. Także niejednokrotnie trudno byłoby oddzielić wypowiedzi na temat samego śmiechu jako reakcji psychofizycznej od opinii, które odnoszą się do tego, co ową reakcję powoduje. O śmiechu bowiem mówi się przeważnie w powiązaniu $\mathrm{z}$ jego przyczyną, a przede wszystkim $\mathrm{z}$ funkcją, czy ze względu na potrzebę takiej lub innej racjonalnej nad nim kontroli. Formułowane sa przy tym zarówno uwagi opisowe, jak i postulatywne.

$\mathrm{W}$ wypowiedziach będących tu przedmiotem zainteresowania poza wyjaśnieniami odnośnie do samej natury komizmu i śmiechu znajdujemy próby ujęcia problemu z perspektyw retorycznej i etycznej, kiedy pojawia się pytanie o skuteczność dydaktycznego oddziaływania zabiegów komicznych w literaturze, a także o zasadność, z punktu widzenia słuszności moralnej, stosowania niektórych z nich w konkretnych sytuacjach. Niekiedy, głównie w przypadku charakteryzowania komedii, formułowane są rady dotyczące poczynań zapewniających większą efektywność w tym zakresie. Wreszcie śmieszność (komizm) opisana zostaje jako kategoria estetyczna, $\mathrm{z}$ uwzględnieniem jej zróżnicowania oraz związku z treścią takich pojęć jak komedia, satyra, heroikomika, burleska czy farsa.

Za powszechnie znany, również w okresie oświecenia, więc tu cytowany jedynie dla porządku, należałoby uznać pogląd przedstawiony w Poetyce Arystotelesa, iż śmieszność ,jest częścią brzydoty”, a: 
To, co śmieszne, jest przecież związane $z$ jakąś pomyłką lub z bezbolesnym i nieszkodliwym oszpeceniem, czego wymownym przykładem, żeby nie szukać daleko, jest brzydka i powykrzywiana, lecz nie wyrażająca bólu, maska komiczna? ${ }^{7}$.

Autorzy oświeceniowi - kontynuując w dużej mierze przekonania formułowane na gruncie estetyki klasycyzmu - kategorię tę wiązali często z dydaktyczną funkcją dzieł literackich, przede wszystkim komedii, ale także utworów należących do takich gatunków, jak satyra czy poemat heroikomiczny. Nie jest to jednak już wówczas powszechnie dominujący pogląd, gdyż z jednej strony literacki komizm oświeceniowy - co też wielokrotnie zauważano - służy nierzadko w założeniu celom również, lub nawet wyłącznie, rozrywkowym, a z drugiej pojawia się coraz częściej zwątpienie w jego potencjał dydaktyczny ${ }^{8}$, czego najbardziej wyrazista ilustracje stanowia choćby poglądy Jeana-Jacques'a Rousseau odnoszace się do komedii w jego Liście o widowiskach skierowanym do Jeana Le Ronda d'Alemberta ${ }^{9}$.

Niejdnokrotnie opinie dotyczące prezentowanego zjawiska formułowane sa podobnie jak w przypadku Stagiryty - w związku z omawianiem właśnie komedii (a przykłady pochodzą zazwyczaj z konkretnych realizacji owego gatunku), jakkolwiek nierzadko, nawet jeśli nie zaznaczono tego wyraźnie, problem ujęty zostaje jednak szerzej. Tytułem wprowadzenia warto przywołać tutaj poglądy na ten temat popularnych u nas w okresie oświecenia i mających kluczowy wpływ na ówczesna polską myśl estetycznoliteracką Charles'a Batteux oraz Jeana-François Marmontela. Pierwszy z nich w dziele Les Beaux-Arts réduits à un même principe (Sztuki piękne sprowadzone do tej samej zasady) rozumie śmieszność (le ridicule) jako zestawienie razem rzeczy wyraźnie niepasujących do siebie ${ }^{10}$. Jest ona niemal wszechobecna - twierdzi francuski autor - ale niewielu potrafi ją rozpoznać, a jeszcze mniej znaleźć można geniuszów, którzy są w stanie wykorzystać ją delikatnie i w taki sposób, żeby łączyła funkcje podobania się i pouczania, czyniąc to bezkonfliktowo, bez ograniczania potencjału jednej czy drugiej.

Batteux dokonuje - w zależności od tego, jacy ludzie i jakie obyczaje stanowia przedmiot naśladowania - podziału komizmu (le comique ${ }^{11}$ ) na wysoki i niski. Pierwszy, jak twierdzi, rozśmiesza tylko umysł, występuje tam, gdzie uczucia sa

7 Ary s t o teles, Poetyka. W: Retoryka. - Poetyka. Przekł., wstęp, koment. H. P o d bi els ki. Warszawa 1988, s. 322. Nie ma, oczywiście, potrzeby przywoływania w tym miejscu całej niezwykle bogatej literatury przedmiotu dotyczącej komizmu i śmiechu. Nie będą też w zasadzie podejmowane próby - poza przypadkami, kiedy wyda się to istotnie użyteczne - „tłumaczenia” pojęć, którymi posługiwali się autorzy oświeceniowi, na terminy, które wykorzystywane są w dzisiejszej refleksji na owe tematy.

8 Tę sprawę w szerokim ujęciu omawia J. Gold zi n k w książce Les Lumières et l'idée du comique ( $\langle$ Oświecenie a pojęcie komizmu〉 Lyon 1992).

9 Zob. J.-J. Ro u s s e a u, List o widowiskach. W: Umowa społeczna. - List o widowiskach. Warszawa 2010, s. 166 (przeł. W. Bi eń k ow s ka): „Przesada nie czyni przedmiotów wstrętnymi, czyni je tylko śmiesznymi, a to ma tę złą stronę, że lęk przed śmiesznością przysłania przerażenie, jakie budzą wady; niepodobna naprawiać ich, nie wyolbrzymiając komizmu. [...] dobrzy nie ośmieszają złych, ale ich druzgoca pogardą. I nic nie jest tak przykre i dalekie od śmiechu, jak święte oburzenie cnoty. Śmieszność, przeciwnie to ulubiona broń występku. Atakując nią w głębi serc szacunek, którym powinno się otaczać cnotę, niszczy się w końcu miłość do niej”. 
delikatne, a rozmowy przyprawione dowcipem, należy do manier dobrego towarzystwa; natomiast drugi, niski, jest właściwy ludziom $z$ warstw niższych, mniej wyrafinowanym, których gust pozostaje zgodny $z$ otrzymaną przez nich edukacją. Nie powinno się wszakże i w takim przypadku akceptować grubiaństwa, lecz jedynie naiwność, prostotę i naturalny, niezdradzający żadnego wysiłku dowcip. Można byłoby wskazać jeszcze trzeci rodzaj komizmu, oparty na prymitywnej burlesce, ale ten, zdaniem Batteux, nie zasługuje na to miano ${ }^{12}$, zatem - jak wnioskujemy $z$ toku jego wywodu - nie powinien znajdować się w literaturze; nie wszystko w tym zakresie może być przedmiotem naśladowania.

Później, w traktacie Principes de la littérature (Zasady literatury), francuski autor rozwija ów problem, wskazując chociażby sposoby uzyskiwania efektu komicznego i przywołując odpowiednie przykłady z komedii Moliera. Bardziej też niuansuje spojrzenie na podział komizmu, zauważa, że między komizmem wysokim a niskim istnieje wiele dających się pomyśleć jego postaci pośrednich i być może konstatuje Batteux - właśnie wśród nich pojawia się komizm najdoskonalszy, który rozwesela zarówno wyobraźnię, jak i rozum ${ }^{13}$.

Marmontel natomiast, który tej kwestii poświęca oddzielne opracowanie w ramach swoich Éléments de littérature (Elementów literatury), podkreśla związek komizmu $\mathrm{z}$ konkretnymi miejscem i czasem, gdyż to, co jest komiczne dla danej społeczności lub danego człowieka, może nie być takie dla innych i w odmiennych okolicznościach. Autor zauważa jednak - odwołując się każdorazowo do komedii Moliera - że istnieją sytuacje, w których komizm, odnosząc się do wad powszechnych, zachowuje wszędzie swoją żywotność.

Marmontel wyróżnia komizm szlachetny (noble), mieszczański (bourgeois) i niski (bas). Pierwszy maluje obyczaje wielkich, arystokracji; ich wady sa mniej grubiańskie, śmieszności mniej szokują, tak zostają upiększone przez grzeczność, że niewielu może je uchwycić. Komizm mieszczański - którego przykład przynosi Mieszczanin szlachcicem - obraca się wokół pretensji przedstawicieli tej grupy społecznej do naśladowania wielkiego świata. Komizm niski natomiast odzwierciedla obyczaje ludu, jakkolwiek - podkreśla Marmontel - nie powinien sprzeciwiać się gustowi i obyczajom, także on obdarzony jest delikatnością i wdziękiem. Nie można zatem mylić go $z$ komizmem grubiańskim (grossier), którego właściwie nie należy traktować jako oddzielnego rodzaju komizmu; jest on, powiedzielibyśmy, komizmem fałszywym ${ }^{14}$. Jak widać, zarówno Batteux, jak i Marmontel, zajmując się omawianą tu kwestią w odniesieniu do literatury, wyłączają poza zakres zainteresowania przejawy śmieszności całkowicie żywiołowe, nieokiełznane, niepoddane w żadnym stopniu kontroli rozumu czy gustu.

Wśród wypowiedzi formułowanych w Polsce w XVIII wieku ${ }^{15}$ także powtarzaja się, dość lakoniczne, uwagi o dydaktycznej funkcji komedii, przy czym mielibyśmy tu

Ch. B a t te ux, Principes de la littérature. Paris 1775, s. 173.

J.-F. M a r m o n t el, Comique. W: Éléments de littérature. Édition présentée, établie et annotée par S. Le Ménahèze. Paris 2005, s. 293.

15 Zwięzły przegląd większości istotniejszych opinii na ten temat zamieścił R. Doktór w książce Poeta uśmiechnięty. O wyobraźni komicznej Ignacego Krasickiego (Wrocław 1992, s. 17-122). 
głównie do czynienia (podobnie jak u Arystotelesa) z koncepcją komizmu określoną przez Bohdana Dziemidoka jako „teoria cechy ujemnej przedmiotu komicznego i wyższości podmiotu przeżycia komizmu nad przedmiotem tego przeżycia”, w wersji, dodajmy, obiektywistycznej ${ }^{16}$. Już Ignacy Krasicki na łamach „Monitora” potwierdza dominujące wówczas przekonanie, iż komedia „śmiech wznieca i prowadzi do obrzydzenia przywar cnotom towarzyskim przeciwnych" ${ }^{17}$. Podobną opinię formułuje poświęcający sporo uwagi charakterystyce tego gatunku Adam Kazimierz Czartoryski, według którego „drwieniem z osób szydnych pobudzając nas do śmiechu, zakłada sobie komedia poprawić w nas defekta, które wystawia, i lepszymi nas w towarzystwie uczynić" ${ }^{18}$. Filip Neriusz Golański w znanej rozprawie $O w y$ mowie i poezji pisze wreszcie, że komedia „widokiem swoim rozweselając tych, którzy na nię dla zabawy przychodzą, poprawia ich razem i naucza [...]"19. Można jeszcze też przywołać tu utwór Franciszka Bohomolca Autor komedii pokazujący m.in. kryzys tego gatunku w jego klasycznej wersji, co wiąże się w dużym stopniu ze wspomnianym wcześniej kwestionowaniem zasadności używania śmiechu jako narzędzia oddziaływania dydaktycznego ${ }^{20}$. Główny bohater komedii Bohomolca, Prawdomowski, tkwi jednak nadal w przekonaniu, że „najpierwsza komedii powinność jest śmiechem obyczaje poprawować" 21 .

Skupiając się na innych aspektach interesującego nas zagadnienia omawianych w polskim piśmiennictwie oświeceniowym, na początek warto przyjrzeć się dość obszernej rozprawie eksjezuity Michała Dudzińskiego pt. Dysertacja o śmiechu, opublikowanej na łamach „Zabaw Przyjemnych i Pożytecznych” w 1775 roku $^{22}$. Zamieszczone w niej rozważania, jakkolwiek nie przynoszą może szczególnie oryginalnych refleksji, powtarzając np. wiele myśli sformułowanych na gruncie retoryki antycznej, zwłaszcza przez Cycerona i Kwintyliana ${ }^{23}$, podejmują też kwestie, które okazują się istotne w określaniu oświeceniowej postawy wobec tego problemu.

Dudziński stara się zgłębić zagadnienie dość wnikliwie i wyraźnie wyznaczyć

B. D z i e m i d o k, O komizmie. Od Arystotelesa do dzisiaj. Antologię oprac. M. B o k i n i e c. Gdańsk 2011, s. 12. Badacz mówi o teoriach obiektywistycznych, subiektywistycznych i relacjonistycznych, wyodrębnionych ze względu na to, „gdzie dana teoria poszukuje istoty komizmu: w sferze przedmiotów, w sferze przeżyć czy też w sferze relacji między przedmiotami percepcji a podmiotem postrzegającym" (ibidem, s. 13). Na potrzeby niniejszego artykułu, w którym ma znaczenie jedynie ogólne przyporządkowanie przywołanych istotnych koncepcji komizmu do którejś z tych teorii, wykorzystywane jest tylko przeciwstawienie: obiektywistyczny-subiektywistyczny (z założeniem, że w konkretnych przypadkach mogą wchodzić w grę elementy relacjonizmu). I. Kra sicki, $\langle O$ dramacie $i$ teatrze $\rangle$. W zb.: Oświeceni o literaturze. [T. 1:] Wypowiedzi pisarzy polskich 1740-1800. Oprac. T. Kostkiewiczowa, Z. Goliński. Warszawa 1993, s. 72. A. K. Czart ory s ki, Przedmowa do „Panny na wydaniu”. W zb.: jw., s. 109-110.

19 F. N. Golańs ki, O wymowie i poezji. W zb.: jw., s. 343.

20 Zob. np. F. K. D moch ow ski, Sztuka rymotwórcza. Poema we czterech pieśniach (w zb.: jw., s. 407), gdzie mamy - jak już nieraz zauważano - akceptację dla komedii, która oddziałuje poprzez dobry przykład, nie ośmieszanie, gdyż „Śmiech prędko niknie - czułość wskroś serca przenika”.

21 F. B o h o mole c, Autor komedii. Komedia w trzech aktach. W: Komedie na teatrum. Oprac., wstęp J. Kott. Warszawa 1960, s. 456.

22 M. Du dzińs ki, Dysertacja o śmiechu. „Zabawy Przyjemne i Pożyteczne” 1775, t. 12, cz. 2.

23 Zob. uwagi o znaczeniu śmiechu w poglądach retorycznych tych autorów - M. N o w a k, „Multum facetias in dicendo prodesse saepe” (Cic. De or. II 227). Dowcip w retorycznej teorii i praktyce. „Symbolae Philologorum Posnaniensium Graecae et Latinae" 2010, nr 1. 
jego zakres, wychodząc z założenia, że „nie wszystko, co na pierwsze wejrzenie zda się być śmieszne, w samej rzeczy jest takim, ani każdy śmiech śmiechu jest godzien" 24 . Autor akcentuje, wracając do tego niejednokrotnie w rozprawie, znaczenie śmiechu jako odróżniającego człowieka od zwierząt, zatem - jak twierdzi - gdyby kto chciał przypisać im możliwość śmiechu, „tym samym przyznawałby im rozum [...]”25. Skoro zaś właśnie rozumność człowieka decydować może o jego śmianiu się, to zdolność taka będzie ściśle związana ze sferą racjonalną ludzkiej świadomości. Emocje, szczególnie te, które ludzie mają wspólne ze zwierzętami, w zasadzie sprzeciwiają się komizmowi. Dudziński wyjaśnia w innym miejscu, że sama skłonność do śmiechu pochodzi z rozumu i jest właściwa wszystkim ludziom, natomiast różnice w tym zakresie uwarunkowane zostaja przez czynniki cielesne. Ta obserwacja jest istotna zarówno w odniesieniu do wyjaśniania źródła oraz natury zjawiska, jak i ze względu na potrzebę, tak często eksponowaną w epoce oświecenia, pewnej świadomej kontroli nad śmiechem.

Zajmuje uwage autora Dysertacji o śmiechu także sprawa związku między samym śmiechem jako reakcją fizyczną a stanem umysłu człowieka śmiejącego się i zewnętrzną przyczyną, która ów stan powoduje. W dalszej kolejności Dudziński dochodzi do wniosku, że śmiech łączy się też z pewną przyjemnością, która jednak potrzebuje w tym przypadku mieć w sobie „coś dziecinnego”, z czego $z$ kolei wynika choćby fakt, że „poważnego męża rzadko kiedy obaczysz śmiejącego się, a i to pomiarkowanie [...]"26. Podkreśla autor znaczenie czynnika zaskoczenia, nowości w stwarzaniu źródła śmiechu, zastanawia się również nad bardzo ciekawą kwestią (choć bez jej rozstrzygania), dlaczego coś z natury niebudzącego śmiechu wywołuje taki efekt, gdy staje się przedmiotem udawania.

Autor rozprawy zaznacza przy tym, że sama umiejętność rozśmieszania jest cechą wrodzoną, niezależną od wykształcenia, jednak sposób wykorzystania owych predyspozycji bywa różny, może także stanowić rezultat edukacji. Stąd - czytamy dalej - „dowcipni a mądrzy ludzie w dowcipnych powieściach i żartach smakują [...]”, natomiast głupi „i dzieci $z$ lada czego śmieją się, bo im wszystko dziwno się być zdaje. Dobrze więc mówią: poznać głupiego po śmiechu [...]"27. Widzimy, że Dudziński również zwraca uwagę na problem, który z reguły bywał wówczas podstawą do wyróżniania komizmu wysokiego i niskiego (jakkolwiek sam takiego podziału jednoznacznie nie czyni), przy czym ten pierwszy, odnosząc się do osób wykształconych, waloryzowany byłby tu wyraźnie wyżej.

Czytamy w rozprawie również o ścisłej zależności śmiechu nie tylko od wrażliwości i kompetencji tych, którzy się śmieją, ale też od innych czynników - jak znajomość pewnych szczegółów, stosunek do osób biorących udział w owej potencjalnie śmiesznej sytuacji - związanych z konkretnymi okolicznościami, kiedy może pojawić się lub nie tego rodzaju reakcja. Dudziński akcentuje także aspekt moralny śmiechu, ponieważ nie zawsze jest on „przystojny”, np. gdy jest za bardzo głośny albo za długi, zatem należy nauczyć się odpowiedniej nad nim rozumowej kontro- 
li: „Rozum ci to jest, którym niby ostrzem jakim wszystko to, co jest zbytecznego, precz odcinać mamy"28.

Wiele myśli zawartych w Dysertacji o śmiechu zostaje podjętych także przez innych autorów, choć często są one wyrażone w nieco odmienny sposób. Wystarczy wrócić jeszcze do Autora komedii, gdzie Prawdomowski podkreśla w konfrontacji z przeciwnymi opiniami (zapewne wypowiadając poglądy Bohomolca), wartość samego śmiechu, przypomina - jak Dudziński - że jest to typowo ludzkie zjawisko:

Inne namiętności, jako to: gniew, żal, bojaźń, zazdrość i tym podobne, mają i zwierzęta, ale śmiech do człowieka tylko należy. Dlatego niektórzy dawni filozofowie, chcąc pokazać między bydlętami i człowiekiem różnicę, nazwali go animal risible ${ }^{29}$

Śmiech może być - utrzymuje Prawdomowski - bardzo korzystny ze względów zdrowotnych, kiedy wiąże się $\mathrm{z}$ wesołością, która „serce otwiera, krew naprawuje, humory rozrzadza" ${ }^{30}$. Oczywiście, należy w tym zakresie zachować umiar, więc tenże bohater $-\mathrm{w}$ reakcji na uwage jednego $\mathrm{z}$ adwersarzy przytaczającego opinię (zawartą też w rozprawie Dudzińskiego), iż „per risus multus cognoscitur stultus” ${ }^{31}$ podkreśla, że on mówi o śmiechu „pomiarkowanym i rozumnym”32.

Takie tedy podejście do śmiechu jako czegoś w istocie bardzo pozytywnego, pod warunkiem jednak zachowania właściwego umiarkowania, charakteryzuje postawę znaczącej części autorów epoki oświecenia. Zostało ono dość zwięźle, lecz dobitnie choć przy użyciu innych terminów: wesołość i żart, faktycznie odnoszących się do szeroko ujętego zagadnienia śmiechu - sformułowane np. w zaakceptowanym przez Komisję Edukacji Narodowej podręczniku Grzegorza Piramowicza Wymowa i poezja dla szkót narodowych:

Wesołość miła jest ochłodą życia i towarzystwa ludzkiego, wesołość mowy i z duszy pochodzić i do duszy płynąc powinna. Powabu przyjemności nie odrzuca mądrość i cnota, żeby pewniej i pospoliciej przyjęte były. Lecz nie masz nic niebezpieczniejszego, jak chcieć zawsze być wesołym, zawsze rozweselać. Żart zręcznie rzucony wiele skutku sprawi ku usłudze prawdy. Ale natykać żarciki i jedne drugimi gonić, lekkiego, a często złośliwego umysłu jest znakiem ${ }^{33}$.

Na oddzielny komentarz zasługuje jeszcze Krasicki, którego twórczość nierzadko analizowana jest w perspektywie zabiegów komicznych, jakkolwiek nie podejmuje on w zasadzie wnikliwszej, systematycznej i bardziej rozwiniętej refleksji nad natura omawianego zjawiska; niejednokrotnie formułuje, zwykle jakby mimochodem, efektowne, tu i ówdzie rzucone komentarze na ten temat, przyjmujące niekiedy postać sentencji. Przygląda się tej kwestii Roman Doktór, który wychodząc od obserwacji, iż dla XBW istotne było zarówno to, co wywołuje śmiech, jak i sama owa reakcja, stwierdza, że uwagi poety odnośnie do komizmu i śmiechu „nie ukła-

Ibidem, s. 288.

B o h o molec, op. cit., s. 457.

Ibidem, s. 461.

Ibidem, s. 457.

Ibidem, s. 458.

G. Pi r a m o w i c z, Wymowa i poezja dla szkót narodowych. W zb.: Oświeceni o literaturze, s. 553. 
dają się w żadną spójną teorię" ${ }^{34}$. Dalej jednak formułuje konstatację, iż da się z nich „wypreparować jakąś ogólną myśl”, a w konsekwencji wskazuje trzy postawy XBW wobec tego problemu:

Generalnie można stwierdzić, że autor Myszeidy miał przekonanie o istnieniu śmiechu budującego, satyrycznego, który czemuś może służyć, ma moc poprawiania rzeczywistości. Ale też wspomniał o szyderstwie, naśmiewaniu się, które ma za cel zniszczenie. Krasicki wspomina też o śmiechu bezinteresownym, humorystycznym, wypływającym po prostu $z$ dobrego samopoczucia ${ }^{35}$.

Badacz przywołuje dalej szereg uwag i wypowiedzi poety ilustrujących tę syntetyczną obserwację ${ }^{36}$. Nie ma potrzeby powtarzania ich wszystkich. Należy jednak jeszcze podkreślić, iż również XBW prezentuje się wyraźnie i wielokrotnie jako zwolennik zachowania umiaru w używaniu śmiechu w funkcji metody wychowawczej, nieprzekraczania przy tym granic przyzwoitości, co przedstawia choćby w znanej (więc nie trzeba jej w całości przytaczać) oktawie z Monachomachii:

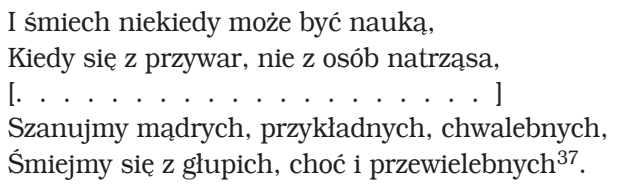

Mamy naturalnie jeszcze wiele innych wypowiedzi poety „o praktycznym wykorzystaniu żartu" ${ }^{38}$, a także o nieaprobowanym w zasadzie przez Krasickiego złośliwym naśmiewaniu się, śmianiu się lub wywoływaniu (nawet niezamierzenie) śmiechu w niewłaściwych momentach -

\footnotetext{
Różne są ludzkie zdania: ci w lewą, ci w prawą,

Ci chca nazbyt powolnie, tamci nazbyt żwawo,

Ci płakać z Bewerlejem, ci śmiać z Donkiszotem,

Więc autor, ustawicznym strudzony kłopotem,

Gdy do usług publicznych z swym dziełem pośpiesza,

Chcąc ucieszyć - frasuje, chcąc smucić - rozśmiesza ${ }^{39}$.
}

- czy o próbach natrząsania się $z$ istotnych wartości albo po prostu $z$ naiwności kierowanej dobrymi intencjami: „Śmiali się z niego, / Bo z poczciwego” ${ }^{40}$. Należy przy tym zauważyć, że Krasicki nie łączy jednoznacznie nawet aktu ośmieszania z ocena moralną. W dziele $O$ rymotwórstwie i rymotwórcach stwierdza lakonicznie:

Doktór, op. cit., s. 23.

Ibidem.

Ibidem, s. 23-33.

I. Kr a si cki, Monachomachia. W: Dzieła zebrane. Seria 1: Pisma literackie. T. 1: Poematy. Oprac. Z. Goliński. Wrocław 1998, s. 159. Interesujące jest spostrzeżenie J. T. Pokrzywniaka (Roztrzasania i rozbiory. Czy śmiech może być nauką? „Teksty. Teoria literatury, krytyka, interpretacja” 1978, nr 6, s. 107), który zwraca uwagę na słowo „niekiedy” w tym fragmencie, stawiając pytanie: „Czy znaczy to, że śmiech może być nauką, byleby był z przywar, a nie z osób, czy też, nawet jeśli jest to śmiech z przywar, niekiedy tylko może być nauka?"

Dok tó r, op. cit., s. 24.

I. Kra sicki, Listy. 7: Do pana Rodkiewicza. W: Dzieła zebrane. Seria 1: Pisma literackie. T. 2 : Zbiory wierszy. Oprac. T. Ko st ki e w i c zow a. Poznań 2019, s. 194.

I. Kra sic ki, Listy z wierszami. 34: Do S. W: jw., s. 311. 
Jak tragedia naśladowaniem jest dobrego, komedia to, co złe na widok stawia, nie złego jednak w powszechnym użyciu; to co wyszydzenia albowiem godne, niekiedy złym w istocie nie jest ${ }^{41}$.

Bez wątpienia na głębszy jeszcze (choć ta kwestia w bogatej lekturze przedmiotu dotyczącej twórczości Krasickiego wielokrotnie się pojawia) namysł - uwzględniający również „praktykę” poety w tym obszarze - zasługiwałyby zagadnienia komizmu i śmiechu jako wyznaczników postawy XBW wobec świata nacechowanej mniejszym lub większym dystansem. Wymagałoby to jednak odrębnego opracowania, przywołującego może także pewien obszar refleksji filozoficznej. W zakresie, który obejmuje niniejsze rozważania, warto natomiast jeszcze dodać, iż najbliższy Krasickiemu jest - jak się wydaje - śmiech określany przezeń w różnych miejscach jako „niewinny”, służący przede wszystkim (co jednak nie musi oznaczać, że wyłącznie) zabawie. Stąd np. zachęta w ostatniej oktawie Wojny mnichów: „Czytaj i pozwól - niech czytają twoi, / Niech się z nich każdy niewinnie rozśmieje" 42 .

W sposób nieco bardziej rozbudowany XBW formułuje podobny pogląd w szkicu Szyderstwo napisanym pod koniec życia, wchodzacym w skład Uwag:

Żart $\mathrm{z}$ istoty swojej jest miłą, a oraz uszczypliwą powieścią; ale kto się na nim zna dobrze, umie tak tłumaczyć uszczypliwość, iżby była podobieństwem zaczepki, a nie samą zaczepką; przymówką, a nie obraźliwą mową; a na koniec, biorąc $\mathrm{z}$ wyrazu porównanie, aby była tak delikatnym uszczypnieniem, izby po nim znaku nie było. Tak żartować przystojność nie zakazuje, i owszem, zachęca ku niewinnej zabawie ${ }^{43}$.

Można zapewne ogólnie stwierdzić, że przywołane (a także inne, odnoszące się do wesołości czy dobrego nastroju) wypowiedzi Krasickiego pokazuja jego - by tak rzec - afirmację poczucia humoru, przy czym byłby to w przeważającej mierze humor określony przez Juliusza Kleinera jako „pogodny, dobrotliwy, humor we właściwym znaczeniu" 44 .

Od nieco innej strony ujmuje omawiany tu problem Józef Szymanowski w jednej $\mathrm{z}$ not w Liście o guście, czyli smaku. Temat komizmu wprowadza on bowiem w kontekście wypowiedzi o roli gustu, wyjaśniając, na czym polega jego respektowanie „w żartobliwym osobliwie rodzaju pisania, i w dramatycznym”, co oznacza, iż chodzi o umiejętność, którą przynajmniej w jakimś zakresie, podobnie jak sam gust, można doskonalić ${ }^{45}$. Trzeba zatem starać się:

1. Aby żart był z konceptem. 2. Aby wszystek koncept nie zasadzał się na zimnej aluzji lub przekręceniu słowa. 3. Aby żart był przyzwoicie mieszczonym w ustach, z których wychodzi, to jest: uważać, czyli przystoi osobie tej pozwalać sobie w takowym żarcie ${ }^{46}$.

Jak pokazują choćby przywołane wcześniej koncepcje Batteux i Marmontela,

I. Kra si cki, O rymotwórstwie i rymotwórcach. Na podstawie autografu i pierwodruku z uzupelnieniami F. K. Dmochowskiego. Transkrypcja, oprac. E. Zielaskowska. Poznań 2017, s. 61.

42 Krasicki, Monachomachia, s. 165.

43 I. Krasicki, Szyderstwo. W: Uwagi. Wstęp, oprac. Z. Libera. Warszawa 1997, s. 270-271.

44 J. Kl e in er, $Z$ zagadnień komizmu. W: W kręgu historii i teorii literatury. Wybór, oprac. A. H u tniki ewicz. Warszawa 1981, s. 682. 
jednym $\mathrm{z}$ istotnych motywów $\mathrm{w}$ oświeceniowej refleksji o komizmie była potrzeba podziałów i rozróżnień w tym zakresie. Podejmuje ów problem Golański, zauważając, że podobnie jak komedia, również „i żart komiczny różnego gatunku bywa”. Często bowiem to, co śmieszy „pospólstwo”, nie wywołuje takiej reakcji u „rozsądnego człowieka”. Dlatego może istnieć „wysoka komika”, którą nie każdy jest w stanie odczuć, albo przynajmniej „gładka i dowcipna”. Przeciwstawiaja się jej - jak wolno sądzić: niżej waloryzowane - „podłe udawania i podłe wyrazy”, które mogą się podobać „podłym ludziom”. Ten drugi rodzaj komizmu najprawdopodobniej obejmowałby, wydzielony przez przywołanych tu autorów francuskich, usytuowany przez nich poza głównym podziałem tej kategorii, komizm grubiański (grossier), ale także najpewniej, przynajmniej w jakimś stopniu, komizm niski. Dlatego Golański proponuje wyróżnić komedię dla „oświeconych i mających gust dobry [...]” oraz „dla pospólstwa” 7 . Warto zauważyć, że o ile choćby Batteux za podstawę klasyfikacji przyjmuje przedmiot naśladowania, czyli temat i treść utworu, o tyle Golański odwołuje się w tym przypadku przede wszystkim do kompetencji i wrażliwości odbiorców, akcentując zwłaszcza to, dla kogo komedia jest przeznaczona.

Na uwagę zasługuje tu także podkreślenie, iż komedia może opierać się głównie na intrydze, charakterach albo na jednym i drugim. Warto wszakże dodać, że podczas gdy Marmontel jako równorzędne komiczne przedmioty komedii wyróżnia komizm charakteru, sytuacji i komizm wzruszajacy ${ }^{48}$, autor rozprawy $O$ wymowie i poezji z niechęcią odnosi się do „komedii rozrzewniającej”, stwierdzając, iż „bardziej do tego trajedia służy"49.

Także cytowany już Czartoryski, który nie podejmuje głębszych rozważań nad źródłem ani naturą komizmu, ale wpisuje swoje opinie na ten temat w ramy szerszej refleksji estetycznoliterackiej, akcentującej potrzebę kształcenia dobrego smaku, podkreśla zasadniczą różnicę między „żartobliwością” a „trefnowaniem” ${ }^{50}$. Jedynie ta pierwsza może właściwie służyć przekazaniu nauki moralnej. Czartoryski odnosi się tutaj do poglądów Josepha Addisona, cytując obszerny fragment jego zamieszczonego w tygodniku „The Spectator” eseju na ten temat ${ }^{51}$. Angielski autor zwraca uwagę na szczególną trudność w skutecznym uzyskiwaniu efektu komicznego, krytycznie $z$ tego punktu widzenia ocenia znaczną część ówczesnych dzieł, które mają na celu wywołanie śmiechu, akcentując, że prawdziwa żartobliwość - bo taki termin jest tutaj używany (w tekście oryginalnym występuje „Humor”, „plaisenterie” zaś we francuskiej wersji „The Spectator”, z której korzystał Czartoryski ${ }^{52}$ ) winna zawsze znajdować się pod kontrolą rozumu. Nie może być za taką uznana, jeśli ulega zbytnio namiętnościom czy wyobraźni. W tym przypadku, jak widać, problemem nie jest zatem rozróżnienie na komizm wysoki i niski, nie rozmaite odmiany, nawet niejednakowo waloryzowane, tego samego zjawiska, lecz określenie 
tego, co jest prawdziwym komizmem, a co nim w istocie w ogóle nie jest, choć za taki próbuje uchodzić. Stąd Addison, za nim natomiast Czartoryski, wyodrębnia żartobliwość fałszywą i „prawą”. Różnica ta zaś nie wiąże się z odmiennością zastosowanych środków w ramach takiego samego zjawiska, ale wynika $z$ samego jego źródła. Ta pierwsza żartobliwość ma bowiem u podstawy fałsz, przeciwny rozumowi, a druga, pozostająca w zgodzie ze „zdrowym rozumem” - prawdę. Niepodobieństwo między nimi objawia się w rodzaju reakcji, jakie wywołują. Żartobliwość fałszywą:

Mogą [...] rozeznać po głośnym i zbytecznym śmiechu, do którego prawie nigdy kompanii nie przyprowadza, bo tak jak prawa żartobliwość, wszystkich śmiesząc, zwyczajnie od śmiechu się sama wstrzymuje, tak nieprawa żartobliwość sama się zawsze śmieje, nie śmiesząc nikogo ${ }^{53}$.

Jak się zatem wydaje, dla Czartoryskiego jedyna właściwa, „prawa” odmiana komizmu to ta, którą inni autorzy nazywają „wysoką”. Wpisuje się to ściśle w jego koncepcję doskonalenia polskiej literatury, mająca u podstawy - jak twierdzi Teresa Kostkiewiczowa - „ideał sztuki nie tylko popularno-wychowawczej, ale odwołującej się do określonej kultury i gustu środowiska elitarnego" ${ }^{4}$.

W oświeceniu postanisławowskim problem śmieszności i komizmu także bywa podejmowany przy omawianiu komedii - chociaż nie akcentuje się już w tym kontekście jej dydaktycznej funkcji - ale niezależnie od tego jest rozwijany też w oddzielnych wypowiedziach. Euzebiusz Słowacki w wykładach na Uniwersytecie Wileńskim wspomina owo zagadnienie, gdy przedstawia komedię, ogólnie zgodnie z tradycyjnym jego rozumieniem:

Śmieszność albo komiczność w komedii wynika czy to z charakterów, czy to z położenia, czyli sytuacji osób, albo z tego obojga razem: i ten ostatni gatunek jest bez wątpienia najmocniejszy ${ }^{55}$.

Warto zauważyć, że mamy tu do czynienia z niemal dokładnym tłumaczeniem słów Johanna Joachima Eschenburga ${ }^{56}$. Dalej, wciąż postępując śladami niemieckiego autora, Słowacki przypomina: „Dzielą pospolicie komiczność na wy ższa i niższą, podział mniej wynikajacy ze stanu i znaczenia osób, jako raczej z ich sposobu działania i mówienia”. Dodaje również, iż gdy drugi z tych „śmieszności gatunków” przeważa w utworze, „taką sztukę nazywamy komedią gminną albo fars a [...]"57.

W podobny sposób ujmuje tę kwestię Józef Korzeniowski w rozdziale Kursu poezyi poświęconym komedii. Wychodzi z, często wówczas formułowanego, przekonania, że trudno jest skłonić do śmiechu „ludzi rozsądnych i wykształconych”. Ponieważ „śmieszność w postępowaniu jest widocznym objawieniem się nierozsądku, niemającym żadnych ważnych skutków [...]”, należy umieć rozpoznawać, „co

Czartoryski, op. cit., s. 111.

T. Kostkiewiczowa, Krytyka literacka $w$ Polsce $w$ epoce oświecenia. W: E. Sarnowska- Temeriusz, T. Kostkiewiczowa, Krytyka literacka $w$ Polsce $w$ XVI $i$ XVII wieku oraz w epoce oświecenia. Wrocław 1990, s. 231.

E. Sło w a c ki, O poezji. W: Dzieła z pozostałych rękopismów ogłoszone. T. 2. Wilno 1826, s. 126. J. J. Eschenburg, Entwurf einer Theorie und Literatur der schönen Wissenschaften. BerlinStettin 1783, s. 173.

Słow a cki, op. cit., s. 126. 
jest rozsądnym i przyzwoitym" 58 . Stąd wynikają różnice w postrzeganiu tego, co śmieszne albo nie przez różne osoby: „Jedni wymagaja głębszego odkrycia wad i zdrożności serca, i charakteru; innych rozśmieszają wady powierzchowne i niedorzeczności najpospolitsze”. Jako właściwe komedie Korzeniowski traktuje tylko takie utwory dramatyczne, w których „wyższa komiczność panuje” ${ }^{59}$. Te natomiast, gdzie dominuje komiczność niższa, nazywa, podobnie jak Słowacki, „f a r s a m i”60.

Ciekawsze sa jednak spostrzeżenia dotyczące śmieszności i komizmu w ramach szerszej refleksji estetycznoliterackiej, w której owe pojęcia sytuowane są - identycznie zreszta jak w przywołanym dziele Eschenburga - w odniesieniu do innych kategorii estetycznych lub z nimi powiązane. Na uwagę zasługują w tym przypadku mające wiele punktów wspólnych, ale i nieco różniące się między sobą koncepcje Euzebiusza Słowackiego i Józefa Franciszka Królikowskiego. Pierwszy z nich w rozprawie Teoria smaku $w$ dziełach sztuk pięknych podejmuje omawianą kwestię w kontekście zagadnień estetycznych, w ramach teorii smaku, gdzie śmieszność traktowana jest jako „uczucie smaku” i zostaje umieszczona oraz scharakteryzowana w jednym rzędzie $z$ takimi kategoriami, jak piękno, nowość, górność, harmonia, gracja. Skoro - zdaniem Słowackiego - śmieszność „przywiązuje nas do rzeczy, myśli, zdań i postępków ludzkich”" ${ }^{\text {, }}$, rodząc przy tym wesołość, można przyjąć, iż jest ona źródłem szczególnego rodzaju przyjemności o charakterze estetycznym ${ }^{62}$.

Autor Teorii smaku próbuje wyjaśnić istotę tego zjawiska:

Rzeczy, z których się śmiać zwykliśmy, mają zawsze podług naszego zdania coś niestosownego i dziwacznego albo coś w sobie względem nas dwuznacznego i niepewnego. Ten szczególny stan umysłu, który śmiech wzbudza, wynika $z$ niepewności naszego sądu, podług którego rzeczy sobie przeciwne zdają się nam być w tymże samym czasie równie prawdziwymi ${ }^{63}$.

Właśnie owa niepewność co do postrzeganego przedmiotu staje się bezpośrednią przyczyną śmiechu. Należy tutaj zaakcentować, że takie ujęcie problemu z perspektywy „stanu umysłu” sytuuje poglądy Słowackiego dotyczące komizmu w ramach - by znów powołać się na Dziemidoka - teorii kontrastu w wersji subiektywistycznej64. Dokładniej rzecz traktując, można je też uznać za bliskie (co nie znaczy identyczne) refleksji na ten temat zawartej w Krytyce władzy sadzenia Kanta. Słowacki eksponuje bowiem - zresztą zgodnie $z$ całym tokiem myślenia zaprezentowanym w Teorii smaku - wymiar podmiotowy także w określaniu fenomenu śmieszności, przesuwa niejako punkt ciężkości z rzeczy na to, jak jawią się one w naszym umyśle i jakie uczucia w nas rodzą ${ }^{65}$.

J. Korzeniows ki, Kurs poezyi. Warszawa 1829, s. 277.

Ibidem.

Ibidem, s. 278 .

E. Słow a cki, Teoria smaku w dziełach sztuk pięknych. Oprac. P. B u k ow i e c. Kraków 2003, s. 83.

To także, jak się wydaje, koresponduje ze sposobem określenia śmieszności przez E s c h e n b u rg a (op. cit., s. 23), według którego nośnikiem walorów estetycznych mogą być nie tylko takie cechy, jak piękno, prawda, dobro i doskonałość, lecz również - stanowiący źródło śmiechu - ich wyczuwalny brak, zatem nieregularność, absurdalność, niestosowność.

Sło w a c ki, Teoria smaku $w$ dziełach sztuk pięknych, s. 84.

Dzi emid o k, op. cit., s. 20-24.

Warto tu przypomnieć zdanie Kanta (op. cit., s. 271): „We wszystkim, co ma wzbudzić głośny, 
Wymienia również i krótko charakteryzuje kolejne źródła śmieszności. Należy do nich przede wszystkim poczucie niepewności, „co sądzić mamy o rzeczy, która nam pod zmysły nasze podpada”. Drugim, a przy tym „najobfitszym” z owych źródeł bywa „niestosowność i niezgodność upatrzona w rzeczach”. Może ona zachodzić między „rzeczą a jej częściami” (karykatura) albo też „pomiędzy rzeczą a jej własnościami”" ${ }^{26}$. Następnie wymienia autor Teorii smaku niezgodność między celem a środkami oraz między przyczyną a skutkiem. Wreszcie czytamy, iż „Śmieszność jeszcze wynikać zwykła z wszelkiej omyłki, ze wszelkiej niestosowności i dziwactwa w chęciach, myślach i słowach"67.

Słowacki powtarza także znaną myśl, że do śmiechu może pobudzać wada albo niedoskonałość, która nie rodzi obaw ani innych negatywnych uczuć ze względu na jej ewentualne skutki. W dalszej części traktatu prowadzi to autora do interesującego wniosku:

Dlatego to ludzie, którzy lubią myśleć, zgłębiać rzeczy i często wszystko w smutnych wystawiać sobie obrazach, nie zwykli śmiać się $z$ tego, co innych do śmiechu pobudza. Wyobrażenie albowiem małej niedoskonałości wiąże się w nich z wielą innymi myślami, które ją powiększają ${ }^{68}$.

Najbardziej rozbudowaną refleksję poświęconą kwestii śmieszności (komiczności) formułuje u nas Królikowski we Wzorach estetycznych poezyi polskiej. Samo rozumienie istoty zjawiska określa on podobnie jak Słowacki, mówiąc przy tym - co trzeba zauważyć - nie tyle o „obiektywnych” własnościach rzeczy, ile o ich postrzeganiu i wynikającym stąd stanie umysłu:

Kiedy w rzeczach postrzegamy brak związku, niemożność pogodzenia przyczyn i skutków, własności itp., kiedy niezgodność ta nie pociagga za sobą żadnego przykrego uczucia ani dla rozważającego, ani dla przedmiotu, który stał się tego przyczyną; natenczas umysł nasz znajduje się w szczególnym położeniu: mniemamy, że się tak rzecz ma, i w tej samej chwili pokazuje nam się przeciwnie: ta niepewność sądu naszego wzbudza w nas rodzaj wesołego usposobienia, które się przez śmiech objawia; a rzecz, która była do tego powodem, nazywamy śmieszna ${ }^{69}$.

Na wzmocnienie tej reakcji (tu powtarza Królikowski wprost za Eschenburgiem ${ }^{70}$ ) wpływaja „rzeczy niespodziewane”, co z reguły ma miejsce w komedii, dlatego - jak czytamy - ten rodzaj śmieszności „powszechnie komicznością nazwano”71. W dalszym wywodzie polski autor używa już tylko takiego pojęcia, jakkolwiek odnosi je nie wyłącznie do komedii, ale do poezji (literatury) w ogóle, sytuując komiczność - podobnie jak Słowacki - wśród innych kategorii i zabiegów estetycznych. Wyróżnia przy tym komiczność wyższą i niższą, traktując je nie jako odmiany ko-

burzliwy śmiech, zawierać się musi coś niedorzecznego (a więc coś, w czym intelekt sam w sobie nie może znajdować upodobania). Śmiech jest afektem, 〈którego źródłem jest〉 nagła przemiana napiętego oczekiwania w nicość".

66 Sło w a c ki, Teoria smaku $w$ dziełach sztuk pięknych, s. 84.

67 Ibidem, s. 85.

68 Ibidem, s. 86.

69 J. F. Królikow s ki, Wzory estetyczne poezyi polskiej $w$ pięknościach pierwszych mistrzów naszych, z przytoczeniem teoryi wystawione. Poznań-Bydgoszcz-Leszno 1826, s. 15.

70 J. J. E s c h e n b u r g, Enwurf einer Theorie und Literatur der schönen Redekünste. Berlin-Stettin 1817, s. 28.

71 Królikowski, op. cit., s. 15. 
medii (staną się one później w jego Rysie poetyki wedle przepisów teoryi $w$ szczegółach najznakomitszych autorów czerpanej podstawą wyodrębnienia tychże odmian ${ }^{72}$ ), lecz jako rodzaje samego zjawiska, przy czym głównym kryterium jest status osób, u których mogą one wywoływać śmiech. Pierwsza występuje wśród ludzi wykształconych, realizuje się głównie w sferze intelektualnej, wymaga zarówno pewnej wiedzy, jak i wyrafinowania oraz respektowania zasad dobrego smaku; stąd - dodaje autor Wzorów estetycznych - „do takiej komiczności potrzeba prawdziwego dowcipu, ażeby nie stać się zimnym, płaskim i wymuszonym [...]"73. Co ciekawe, jako szczególną odmianę komiczności tego rodzaju wskazuje Królikowski „komiczność bohaterską, opartą na kontraście między wysokim i wzniosłym stylem a mało znaczącym, codziennym przedmiotem. Spotykamy ja przede wszystkim w przedstawionym przezeń dokładniej w Rysie poetyki - „poemacie rycersko-żartobliwym" (dziś powiedzielibyśmy heroikomicznym) ${ }^{74}$. Komiczność niższa natomiast odwołuje się do „mowy albo sposobu wystawiania pospolitego gminu [...]”, czyli do osób, dla których cechy komiczności wyższej mogą być nieuchwytne. W tym przypadku nie jest ona ograniczona przez wymóg ogłady intelektualnej, zatem - twierdzi Królikowski - „im bardziej od rzeczy, tym więcej pobudek do śmiechu”75.

Poza tym autor Wzorów estetycznych pisze jeszcze o rodzaju komiczności, którą nazywa „krotofilą” (krotochwila), przywołująca „wyobrażenie ludzi prostych o rzeczach, które za ich obrębem leżą, znalezienie się tych ludzi w stosunkach, które im nie są naturalne [...]"76. Wreszcie Królikowski zwraca uwagę na sytuację, w której rzeczy wielkie i istotne jawią się jako mało znaczące, przypominając, iż w języku francuskim znajdujemy na ich określenie termin „burlesque”, po polsku zaś - jak sądzi - trafna byłoby nazwa „komiczność karczemna”. Godne zaakcentowania jest stwierdzenie, że ona właśnie może być użyta jedynie w „scenach k omiczno-romantycznych"77.

Należałoby ogólnie skonstatować, iż w oświeceniowych wypowiedziach o komizmie i śmiechu daje się dostrzec przechodzenie od koncepcji w przeważającej mierze obiektywistycznych do subiektywistycznych. Przesuwa się też punkt ciężkości w zakresie zainteresowania tym problemem (który warto będzie uczynić w przyszłości przedmiotem wnikliwszych analiz) z płaszczyzny retorycznej i moralnej na estetyczną. Obserwujemy - przede wszystkim w oświeceniu postanisławowskim coraz gruntowniejsze włączanie pojęć związanych $z$ komizmem i śmiechem w szerszą i jednocześnie pogłębioną refleksję nad literaturą.

J.F. Króli k ow s ki, Rys poetyki wedle przepisów teoryi w szczegótach najznakomitszych autorów czerpanej. Poznań 1928. Komedia wyższa „powinna zachować wszystkie prawidła wykształconego smaku” (ibidem, s. 101); co do drugiej na uwagę zasługuje zastrzeżenie, ,aby granice przystojności nie były przestapione" (ibidem, s. 102).

Królikow ski, Wzory estetyczne poezyi polskiej [...], s. 16.

Królikowski, Rys poetyki [...], s. 90.

K rólik ow s ki, Wzory estetyczne poezyi polskiej [...], s. 17.

Ibidem, s. 18.

Ibidem. Trzeba, oczywiście, pamiętać o tym, jak K rólik ow s ki rozumie pojęcie romantyczności, którego nie przeciwstawia klasyczności (ibidem, s. 21-22). 


\title{
Abstract \\ ROMAN DĄBROWSKI Jagiellonian University, Cracow ORCID: 0000-0003-0373-6657 \\ THE ENLIGHTENED ON RIDICULOUSNESS (THE COMICAL) AND LAUGHTER
}

\author{
IN RHETORIC, MORAL, AND AESTHETIC PERSPECTIVE
}

The purpose of the paper is to present and comment on most vital concepts of ridiculousness (the comical) and laughter formulated in the period of the Polish Enlightenment. To some extent it also concerns opinions on this issue produced at that time abroad but known and quoted in Poland. Consideration is focused on the reflections that refer mainly to literature and deal with the mode the comical is understood, the possibilities and need of dividing it, also to those devoted to the function of laughter and accentuating the necessity of reasonable control over it. Ideas by, e.g. Michał Dudziński, Franciszek Bohomolec, Ignacy Krasicki, Adam Kazimierz Czartoryski, Euzebiusz Słowacki, Józef Franciszek Królikowski are recalled. The article shows the shift of attention in capturing the problem from the rhetoric and moral level to aesthetic one, and the continually more distinct process of including the category of the comical into the reflection over the aesthetic values of literature. 